\title{
Pollen viability and incompatibility in indigenous rice bean (Vigna umbellata (Thunb.) Ohwi \& Ohashi)
}

\author{
Maria Lima D. Pascual ${ }^{1,2^{\star}}$, Jerome H. Ruiz ${ }^{1}$, Jimmy A. Posas ${ }^{3}$ \& Marjohn C. Niño $0^{1,2}$ \\ ${ }^{1}$ Molecular and Bioresources Section, Center for Studies in Biotechnology, Cebu Technological University-Barili Campus, 6036 Barili, Cebu, Philippines \\ ${ }^{2}$ Department of Animal and Crop Science, College of Agriculture, Food Science, Business and Communication, Cebu Technological University-Barili \\ Campus, 6036 Barili, Cebu, Philippines \\ ${ }^{3}$ Department of Food Science, Business and Communication, College of Agriculture, Food Science ,Business and Communication, Cebu Technological \\ University-Barili Campus, 6036 Barili, Cebu, Philippines
}

`Email: marialima.pascual@ctu.edu.ph

\section{OPEN ACCESS}

\section{ARTICLE HISTORY}

Received: 08 July 2021

Accepted: 28 October 2021

Available online

Version 1.0 (Early Access): 18 December 2021

Version 2.0:01 January 2022

\section{Check for updates}

\section{Additional information}

Peer review: Publisher thanks Sectional Editor and the other anonymous reviewers for their contribution to the peer review of this work.

Reprints \& permissions information is available at https://horizonepublishing.com/ journals/index.php/PST/open_access_policy

Publisher's Note: Horizon e-Publishing Group remains neutral with regard to jurisdictional claims in published maps and institutional affiliations.

Indexing: Plant Science Today, published by Horizon e-Publishing Group, is covered by Scopus, Web of Science, BIOSIS Previews, Clarivate Analytics, etc. See https:// horizonepublishing.com/journals/index.php/ PST/indexing_abstracting

Copyright: $\odot$ The Author(s). This is an openaccess article distributed under the terms of the Creative Commons Attribution License, which permits unrestricted use, distribution and reproduction in any medium, provided the original author and source are credited (https://creativecommons.org/licenses/ by/4.0/)

\section{CITE THIS ARTICLE}

Pascual M L D, Ruiz J H, Posas J A, Niño M C. Pollen viability and incompatibility in indigenous rice bean (Vigna umbellata (Thunb.) Ohwi \& Ohashi). Plant Science Today. 2022;9 (1):157-166. https://doi.org/10.14719/ pst.1375

\begin{abstract}
Pollen viability, germination and compatibility are essential in determining the success of pollination and seed setting of high-valued crops. Rice bean (Vigna umbellata (Thunb.) Ohwi \& Ohashi) is an underutilized and unexplored indigenous legume with high potential for commercial production. In this study, pollen quality, viability, germination rate and incompatibility among selected six rice bean ( $V$. umbellata) accessions from Barili, Cebu, Philippines were evaluated to determine the barriers and effective pollination habit for increased productivity while retaining the important traits, including high tolerance in poor soils, superior climatic resilience and resistance to pest and diseases. Results of acetocarmine calorimetric assay showed that rice beans' ( $V$. umbellata) pollens are highly viable, with accessions VU $004(56.33 \pm 4.91 \%)$ and VU $007(54.34 \pm 4.53 \%)$ having the optimum viability rate. Brewbaker and Kwack medium treated with $0.2 \mathrm{~g} . \mathrm{l}^{-1}$ and

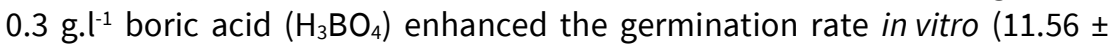
$5.53 \%$ and $9.47 \pm 6.50 \%$ respectively). Bud ( $14.96 \pm 1.53 \%)$ and post-anthesis

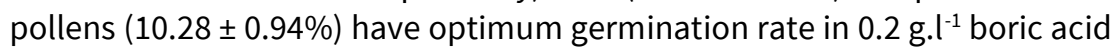
media, while anthesis pollens are suitable in media supplemented with su-

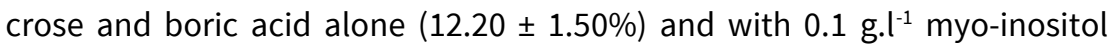
supplementation $(8.49 \pm 1.86 \%)$. Pollination test revealed that rice bean accessions have high self-compatibility $(50.76+3.45 \%)$ and low crosscompatibility $(26.57+2.49 \%)$. The findings provide an important background in understanding the pollen quality and intraspecific interaction among indigenous rice bean ( $V$. umbellata) accessions in Barili, Cebu to improve production and hybridization.
\end{abstract}

\section{Keywords}

Pollen grains, indigenous crop, pollen viability, rice bean, self- and cross incompatibility

\section{Introduction}

In plant breeding, pollen grains play a vital role in developing a high-quality variety. Pollen carries the male gametes responsible for successful genetic exchange and ensures the survival of the species (1). Effective pollination is an essential requirement for fruit development and seed setting in plants (2). Therefore, an insight in to the pollen biology are important in order to improve crop productivity (3); such that knowledge in pollen germinability, viability and the compatibility is a convenient and reliable aspect in future breeding programs (4). 
Pollination in higher plants enables seed development through pollen-pistil interaction (5). However, compatibility and receptibility barriers are problems in the success of the process. Pollen incompatibility is a prefertilization barrier that hinders successful pollination due to: (a) rejection of pollen grains from a male donor by the female receptor flower, (b) failure of pollen grain germination, (c) failure of the pollen tube to reach the ovary and (d) unsuccessful fusion of male and female gametes (6). Incompatibility in plants can be classified as selfincompatibility and cross-incompatibility. Selfincompatibility (SI) occurs when pollen is recognized and rejected by the stigma of plants of the same cultivars (7). On the other hand, cross-incompatibility $(\mathrm{CI})$ is the rejection of pollen by pistil due to lack of recognition of the pollen from the foreign origin (8). Self-incompatibility restricts inbreeding due to self-discrimination of pollen by pistil, while cross-incompatibility $(\mathrm{Cl})$ limits hybrid zygote formation between species of different gene pool $(9,10)$.

Interspecific incompatibility in Vigna species is influenced by the parental genotype and meiotic irregularities (6). It was reported that the crossability of interspecific hybrids among Vigna radiata, Vigna mungo and Vigna umbellata and identified fertilization barriers in some crosses, which resulted to embryo degeneration and abnormal seed development (11). They further identified incompatibility barriers among self- and cross pollinated Vigna species such as delayed entry of pollen tube to the ovules and delayed and failure in nuclear division of endosperm. Reports are on the low crossability and pollen fertility between $V$. radiata and $V$. mungo crosses due to genotypic and ecological differences and meiotic abnormalities (12). One of the determining factors in successful fertilization and germination is pollen viability (13). Pollen viability is vital in seed setting (14), especially in leguminous and grain crops such as Vigna spp. It was reported that over $90 \%$ genetically viable pollens of Vigna unguiculata however the development in in vitro medium resulted to low germination (15). In bambara groundnut (Vigna subterrenea (L.) Verdc.), rapid loss of pollen viability and germinability was reported due to several environmental factors including temperature, humidity and organic solvents used (16).

Like all other legumes, Vigna species is essential in biological nitrogen fixation. In addition, some Vigna species, especially the wild and exotic has resistance to pests and diseases $(17,18)$. Rice bean (Vigna umbellata (Thunb.) Ohwi \& Ohashi), for instance, has been reported to exhibit complete resistance to bruchids, small beetles attacking vignas (6). The most common and widely spread disease among Vigna species, with major economic significance, is the Yellow Mosaic Disease (YMD) caused by Begomoviruses (19). Significant evidences were reported on the high degree of resistance of rice bean ( $V$. umbellata) to the disease compared to other Vigna species $(20,21)$. Rice bean ( $V$. umbellata) has also superior nutritional value comparable to other legume grains (22). Previous studies reported that the crop is rich in amino acids, vitamins, dietary fiber, min- erals such as calcium, iron and zinc and antioxidants such as polyphenols and tannins $(23,24)$.

Although rice bean ( $V$. umbellata) has superior traits and nutritional content, the crop is a less known and regarded as underutilized legume (24). The crop is considered as a minor commodity having less commercial value compared to major agricultural crops of the same class. In addition, underutilized crops are species grown extensively in the past or have a potential in the future either for agronomic, genetic or economic reasons but are currently grown in a limited area. Rice bean ( $V$. umbellata) is among these crop species that did not receive major attention for improvement and thus scientific knowledge about them is limited (22).

Result of initial fragmented studies on its traits provides insights into its potential as a major agricultural crop and as an important genetic resource for breeding. Information on the mode of transfer and retainment of these essential genes to other Vigna sp. (interspecific crossing) or of the same species (intraspecific breeding) is a prerequisite to a crop improvement programme. However, crossability barriers in Vigna sp. hinder the development of interspecific hybrids due to the difference in gene pool, resulting in low fertilization and number of seeds (25). Although several attempts have been conducted to overcome these barriers, reproductive and floral biology has yet been fully explored among intraspecific crosses of rice bean (V. umbellata).

Understanding the pollination habit and reproductive mechanism among crop varieties are essential to increase the chances of successful fertilization $(2,26)$. Since pollen grain carries the traits (27), investigating the pollen biology and mechanism provides essential knowledge in the development of inbreds and hybrids with superior quality. Hence, the objective of this study was to evaluate the pollen quality and incompatibility among native accessions of Vigna umbellata (Thunb.) Ohwi \& Ohashi for improved production.

\section{Materials and Methods}

Plant materials, experimental design and crop management

A total of six rice bean accessions obtained from Barili, Cebu, Philippines and maintained by the Center for Studies in Biotechnology in Cebu Technological University Barili Campus was used in this study. The accessions were assigned with code (VU 001 (Brgy. Balao), VU 002 (Brgy. Kangdampas-San Jose), VU 004 (Brgy. Pangpang), VU 005 (Brgy. Poblacion-market), VU 006 (Brgy. Budbud) and VU 007 (Brgy. Kangdampas-Centro)).

Healthy seeds were used as planting material and propagated in an experimental pot laid out in a Randomized Complete Block Design (RCBD) with three replications and 10 samples per replication.

The experimental setup was maintained following farmer's practice. Soil planting medium, applied with $25 \mathrm{~g}$ chicken dung per pot, was prepared seven days before 
planting. Cultural practices such as weeding using bolo, watering every 4:00 PM and training of vines to climb in their respective stakes were done manually. The setup was covered with a plastic barrier prior to flowering to avoid pollen contamination from other accessions. Flowers were assessed for pollen viability and germination (in vitro and in vivo) assays.

\section{Pollen viability test}

Viable pollen count was estimated using acetocarmine calorimetric assay. Around 32,046 pollen samples were collected in three different plants of the same accession (six accessions) and were spread to a glass slide. A drop of $2 \%$ acetocarmine solution was added to the slide and was examined using a binocular compound light microscope. Pollen is considered viable if it appeared red color and nonviable if colorless after staining (28). Pollen viability was computed using the standard formula (29):

Pollen viability $=$ (number of viable pollen/total number of pollen) x 100 .

\section{In vitro pollen germination test}

Pollen collection was done in 3 different flowering stages: pre-anthesis (bud phase), anthesis (flower fully open) and post-anthesis ( 6 hours after anthesis). Each sample was germinated in a liquid Brewbaker and Kwack (BK) media (30) with different concentrations of boric acid $\left(\mathrm{H}_{3} \mathrm{BO}_{4}\right)$ and varying concentrations of myoinositol (Table 1 ). Then it was incubated at a controlled temperature $\left(27^{\circ} \mathrm{C}\right)$ for $24 \mathrm{hrs}$
Flower buds were enclosed in cellophane bags to avoid pollen contamination from other accessions. Pollination was expected to occur after seven hours and the flower was examined under a compound light microscope. Pollen germination was analyzed as described (35) with slight modifications. Pistils were placed in a $1.5 \mathrm{ml}$ microtube and fixed with three $\mathrm{ml}$ of ethanol: formalin: glacial acetic acid mixture $(8: 1: 1)$ at $4{ }^{\circ} \mathrm{C}$ overnight. The fixed tissues were rehydrated by subsequently submerging in $70 \%, 50 \%$ and $30 \%$ ethanol for 10 min then washed with double distilled water for 10 min instead of submerging overnight. Samples were cleared using $8 \mathrm{~N} \mathrm{NaOH}$ for 30 min, instead of submerging in the solution for $24 \mathrm{hrs}$ and washed three times with sterile double distilled water for another 30 min each. Each tissue was mounted on the slide, then stained with lactophenol cotton blue stain, instead of aniline blue solution, for another $30 \mathrm{~min}$ at temperature $60^{\circ} \mathrm{C}$. A cover slip was gently pressed onto the slide containing the tissue and was examined using a compound light microscope at 400x total magnification. The setup was conducted in triplicate with a total of around 21,535 pollens for interspecific crossing, and around 4,703 for self-pollination were examined. Pollen grains were considered germinated when pollen tube diameter is equal to or greater than the pollen grain diameter itself. The germination rate was estimated using the formula (29):

Pollen germination rate $=$ (number of germinated pollen $/$ total number of pollen) $\times 100$.

Table 1. Pollen germination media (PGM) composition.

\begin{tabular}{cl}
\hline Treatment & Composition \\
\hline $\mathrm{T}_{0}$ & Distilled water (control) \\
$\mathrm{T}_{1}$ & $100 \mathrm{~g} \cdot \mathrm{L}^{-1}$ sucrose $+0.1 \mathrm{~g} \cdot \mathrm{L}^{-1} \mathrm{H}_{3} \mathrm{BO}_{3}+0.3 \mathrm{~g} \cdot \mathrm{L}^{-1} \mathrm{CaNO}_{3} \cdot 4 \mathrm{H}_{2} \mathrm{O}+0.2 \mathrm{~g} \cdot \mathrm{L}^{-1} \mathrm{MgSO}_{4} \cdot 7 \mathrm{H}_{2} \mathrm{O}+0.1 \mathrm{~g} \cdot \mathrm{L}^{-1} \mathrm{KNO}{ }_{3}(\mathrm{Standard} \mathrm{BK}(30) \mathrm{medium})$ \\
$\mathrm{T}_{2}$ & $100 \mathrm{~g} \cdot \mathrm{L}^{-1}$ sucrose $+0.2 \mathrm{~g} \cdot \mathrm{L}^{-1} \mathrm{H}_{3} \mathrm{BO}_{3}+0.3 \mathrm{~g} \cdot \mathrm{L}^{-1} \mathrm{CaNO}_{3} \cdot 4 \mathrm{H}_{2} \mathrm{O}+0.2 \mathrm{~g} \cdot \mathrm{L}^{-1} \mathrm{MgSO}_{4} \cdot 7 \mathrm{H}_{2} \mathrm{O}+0.1 \mathrm{~g} \cdot \mathrm{L}^{-1} \mathrm{KNO} \mathrm{KN}_{3}$ \\
$\mathrm{~T}_{3}$ & $100 \mathrm{~g} \cdot \mathrm{L}^{-1}$ sucrose $+0.3 \mathrm{~g} \cdot \mathrm{L}^{-1} \mathrm{H}_{3} \mathrm{BO}_{3}+0.3 \mathrm{~g} \cdot \mathrm{L}^{-1} \mathrm{CaNO}_{3} \cdot 4 \mathrm{H}_{2} \mathrm{O}+0.2 \mathrm{~g} \cdot \mathrm{L}^{-1} \mathrm{MgSO}_{4} \cdot 7 \mathrm{H}_{2} \mathrm{O}+0.1 \mathrm{~g} \cdot \mathrm{L}^{-1} \mathrm{KNO}_{3}$ \\
$\mathrm{~T}_{4}$ & $100 \mathrm{~g} \cdot \mathrm{L}^{-1}$ sucrose $+0.5 \mathrm{~g} \cdot \mathrm{L}^{-1} \mathrm{H}_{3} \mathrm{BO}_{3}$ (modified Gaaliche et al .28 ) medium) \\
$\mathrm{T}_{5}$ & $100 \mathrm{~g} \cdot \mathrm{L}^{-1}$ sucrose $+0.5 \mathrm{~g} \cdot \mathrm{L}^{-1} \mathrm{H}_{3} \mathrm{BO}_{3}+0.1 \mathrm{~g} \cdot \mathrm{L}^{-1}$ myo-inositol \\
$\mathrm{T}_{6}$ & $100 \mathrm{~g} \cdot \mathrm{L}^{-1}$ sucrose $+0.5 \mathrm{~g} \cdot \mathrm{L}^{-1} \mathrm{H}_{3} \mathrm{BO}_{3}+0.2 \mathrm{~g} \cdot \mathrm{L}^{-1}$ myo-inositol \\
\hline
\end{tabular}

under dark condition. Around 53,873 pollen samples were examined in a binocular compound light microscope (Olympus CX31, Japan) and were considered germinated if the diameter of the pollen tube is equal to or larger than the pollen diameter (31). All setup was replicated three times and the germination rate was estimated using the formula (29):

$$
\text { Pollen germination rate }=\text { (number of germinated pollen } /
$$
total number of pollen) x 100 .

\section{In vivo pollen germination test}

Flower buds with light green color were selected as female parent, before anthesis phase and were emasculated in the late afternoon from 4:00 to 6:00 PM. Emasculation was done during this interval because of the average temperature $\left(20^{\circ} \mathrm{C}\right)$ required for anther dehiscence and increased chances for pollen viability (32). Pollination was performed on the next day from 5:00 to 7:00 AM because high receptibility will be observed in this time interval $(33,34)$.

\section{Data collection and statistical analysis}

All data were recorded and photographed. Data were analyzed using IBM SPSS Statistics version 20. For each quantitative variable, data were subjected to analysis of variance $(p<0.05)$. Individual treatment means were analyzed using post-hoc test (Duncan's Multiple Range Test) and expressed with standard error of means (SEM). .

\section{Results and Discussion}

\section{Pollen viability assay}

Pollen viability is defined as the ability of the pollen grains to germinate (36). Viability is often associated with chromosome arrangement (37) and meiotic regularities $(38,39)$. Acetocarmine stains the cytoplasm and the chromatin material in the nuclei of viable pollen (40). Viable pollen retains the stain, which appears pink to deep red, while sterile pollen does not retain any stain and appears transparent (Fig. 1). The sterility of pollen has been observed in dicots 

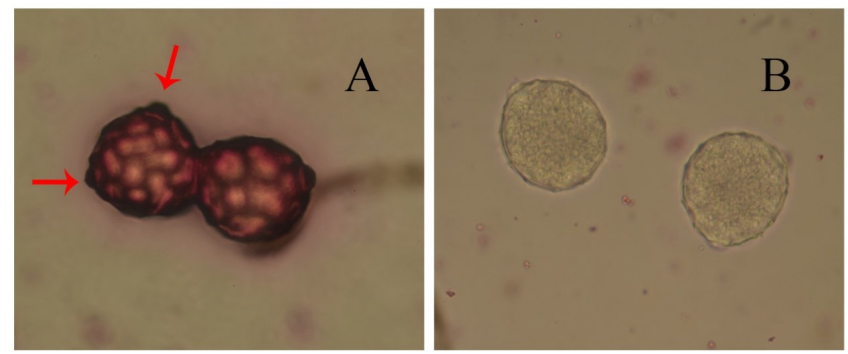

VU 001
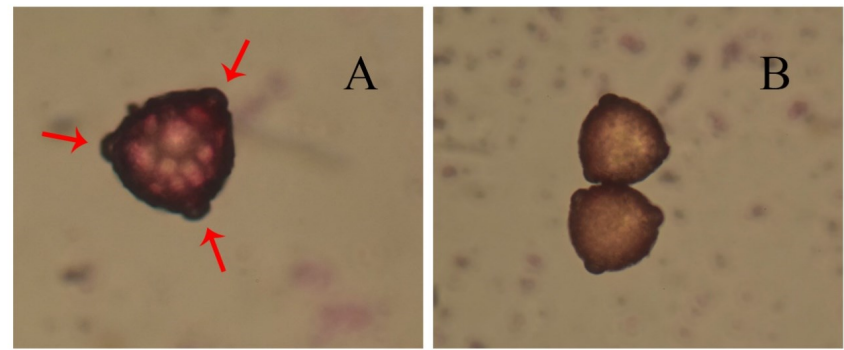

VU 004

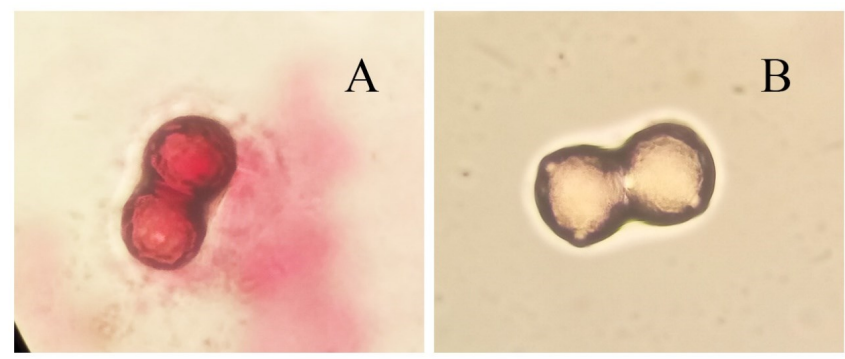

VU 006
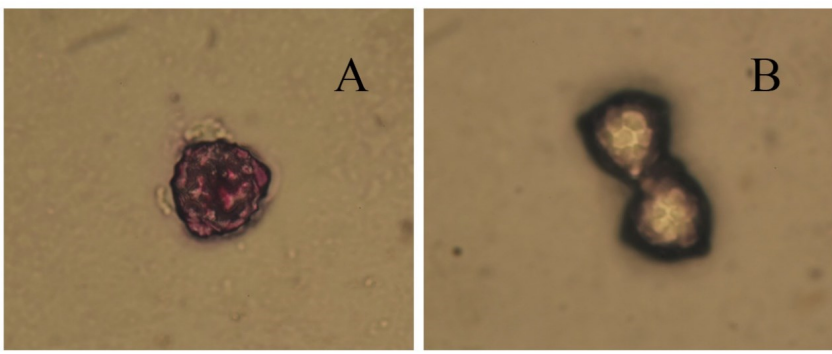

VU 002
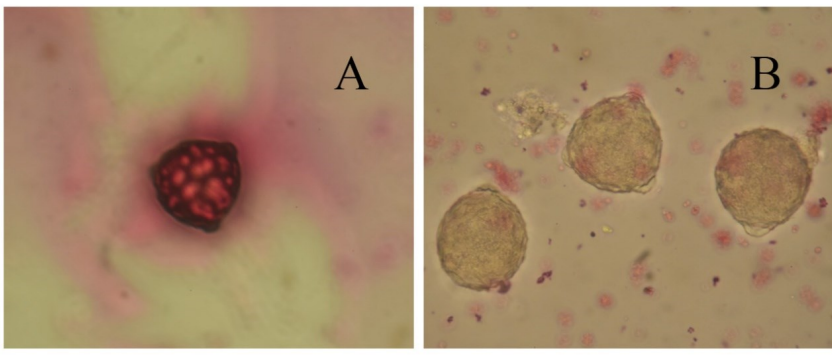

VU 005
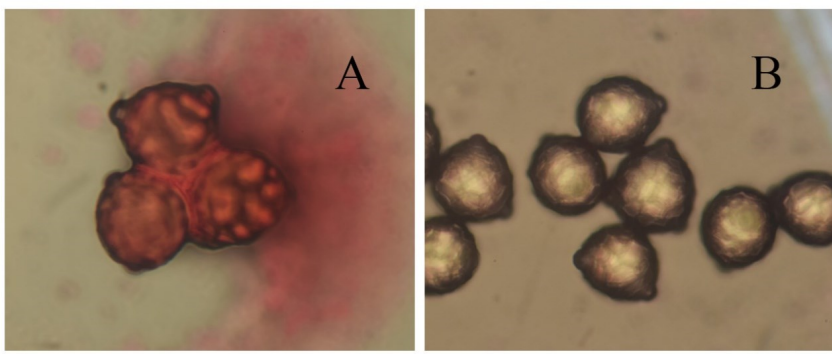

VU 007

Fig. 1. Acetocarmine calorimetric assay of pollen grains in different rice bean (V. umbellata) showing the germinal pore (arrow): (A) Viable and (B) nonviable pollen grains using a compound light microscope at 400x total magnification.

having irregular chromosome segregation, abnormal age pollen viability rate for all accessions is $44.90 \pm 3.14 \%$. sporad formation and unequal-sized fertile pollen grains The overall rate is $49.82 \%$ lower compared to Yard Long (41). Cytomixis on meiotic behavior also affects the viability Bean (Vigna unguiculata subsp. sesquipedalis) (46).

of pollen as observed in wild Himalayan poppy (Meconopsis aculeata Royle) (42). The current study revealed that $V$. umbellata pollen has a tricolporate pollen - having three distinct pores, which is common to all members of Papilionoideae (43-45).

The acetocarmine calorimetric assay revealed that accessions VU $004(56.33 \pm 4.91 \%)$ and VU 007 (54.34 \pm 4.53\%) had the highest pollen viability rate while VU 005 $(28.33 \pm 4.03 \%)$ obtained the lowest rate (Fig. 2). The aver-

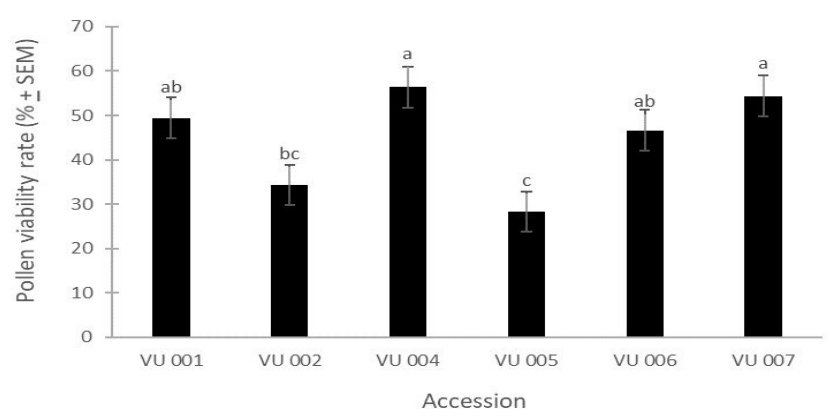

Fig. 2. Pollen viability rate in different rice bean (V. umbellata) accessions. (The same letters indicate no significant difference among accessions using Duncan's multiple range test (DMRT) at $5 \%$ level of significance; $P=0.023$ )
Pollen viability is directly associated with pollen quality and is connected with reproductive biology, determining the effective seed set after pollination (47). The significantly high pollen viability rate in accessions VU 004 and VU 007 increases the chance of effective pollination and higher fertilization rate, indicating strong sexual reproduction and successful seed formation. It was reported that stronger pollen viability is an effective measure for seed setting enhancement (48). Whereas, low pollen viability increases the failure in pollination, which further results in low seed set and reduced breeding efficacy (49).

Optimization of pollen germination medium (PGM) in rice bean (V. umbellata)

In vitro pollen germination test is another method of testing the viability of pollen in artificial media. The medium is generally composed of sugar and ionic salts, such as calcium nitrate, magnesium sulfate and boric acid $(1,28,30,50)$. Organic supplements such as polyethylene glycol, vitamins, amino acids and plant growth hormones were also incorporated to increase the rate of pollen germination (51-53). BK (30) medium is the most widely used pollen germination 
media (PGM) which was tested and was found to be suitable in 86 plant species $(30,54)$.

In the current study, the response of pollen grains of different rice bean (V.umbellata) accessions to boron ( $T_{1}$ $\mathrm{T}_{3}$ ) and myo-inositol $\left(\mathrm{T}_{4}-\mathrm{T}_{6}\right)$ were assessed. A relatively lower overall germination rate $(6.89 \pm 7.09 \%)$ was observed among accessions in the artificial media (Table 2). and $T_{3}$, where bursting were observed, has significantly higher pollen germination rate. Similar results were observed in pollen germination in mango, where bursting was

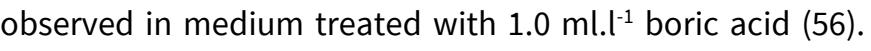
The treatment also resulted in $37.34 \%$ higher germination rate compared to medium without boric acid. In comparison, medium treated with high concentrations of boron

Table 2. Pollen germination rate among rice bean ( $\mathrm{V}$. umbellata) accessions in different medium compositions.

\begin{tabular}{|c|c|c|c|c|c|c|c|}
\hline \multirow{2}{*}{$\begin{array}{c}\text { TR } \\
\text { EA } \\
\text { TM } \\
\text { EN } \\
\text { T }\end{array}$} & \multicolumn{6}{|c|}{ ACCESSION $( \pm$ SEM) } & \multirow{2}{*}{$\begin{array}{c}\text { Average Ger- } \\
\text { mination Rate } \\
\text { (+ SEM) }\end{array}$} \\
\hline & VU 001 & VU 002 & VU 004 & VU 005 & VU 006 & VU 007 & \\
\hline $\mathrm{T}_{0}$ & $1.18 \pm 1.8^{\mathrm{bc}}$ & $1.55 \pm 0.69^{c}$ & $8.17 \pm 2.60^{a}$ & $1.48 \pm 1.03^{c}$ & $5.19 \pm 1.40 \mathrm{bc}$ & $8.18 \pm 1.44^{b}$ & $4.29 \pm 5.30^{b}$ \\
\hline $\mathrm{T}_{1}$ & $9.84 \pm 1.30^{a}$ & $7.18 \pm 1.12^{\mathrm{ab}}$ & $9.59 \pm 2.60^{a}$ & $13.65 \pm 1.02^{a}$ & $9.76 \pm 2.34^{\mathrm{ab}}$ & $11.63 \pm 1.99 a b$ & $10.38 \pm 5.54^{a}$ \\
\hline $\mathrm{T}_{2}$ & $9.27 \pm 1.90^{a}$ & $11.59 \pm 1.31^{a}$ & $12.18 \pm 1.76^{a}$ & $8.66 \pm 0.61^{b}$ & $11.71 \pm 1.45^{a}$ & $15.96 \pm 2.72^{a}$ & $11.56 \pm 5.53^{a}$ \\
\hline $\mathrm{T}_{3}$ & $4.90 \pm 1.68^{a b c}$ & $6.94 \pm 1.52^{\mathrm{ab}}$ & $10.34 \pm 2.22^{a}$ & $7.00 \pm 2.35^{b}$ & $14.17 \pm 1.91^{\mathrm{a}}$ & $13.48 \pm 1.68^{a b}$ & $9.47 \pm 6.50^{a}$ \\
\hline $\mathrm{T}_{4}$ & $5.19 \pm 2.57^{\mathrm{ab}}$ & $7.27 \pm 3.13^{a b}$ & $7.56 \pm 2.36^{a}$ & $6.85 \pm 1.64^{b}$ & $15.05 \pm 2.28^{a}$ & $9.33 \pm 247^{a b}$ & $8.54 \pm 7.68^{a}$ \\
\hline $\mathrm{T}_{5}$ & $2.68 \pm 1.52^{c}$ & $3.68 \pm 1.94^{b c}$ & $0.00^{b}$ & $0.00^{c}$ & $4.79 \pm 2.67^{b c}$ & $12.06 \pm 4.25^{\mathrm{ab}}$ & $3.87 \pm 7.70^{b}$ \\
\hline $\mathrm{T}_{6}$ & $0.00^{c}$ & $0.64 \pm 0.64^{c}$ & $0.00^{b}$ & $0.00^{c}$ & $0.00^{c}$ & $0.00^{c}$ & $0.11 \pm 0.79^{c}$ \\
\hline
\end{tabular}

The $T_{2}$ showed promising results with $11.56 \pm 5.53 \%$ average germination rate for all accessions, with VU 007 having the highest rate $(15.96 \pm 2.72 \%)$. Accessions VU 001, VU 002, VU 005, and VU 007 showed promising pollen germination response in $\mathrm{BK}$ (30) media. On the other hand, VU 004 and VU 006 both have optimum pollen germination response in BK (30) media supplemented with $0.2 \mathrm{~g} . \mathrm{l}^{-1}\left(\mathrm{~T}_{2}\right)$ and $0.3 \mathrm{~g} . \mathrm{l}^{-1}$ $\left(\mathrm{T}_{3}\right)$ boric acid and PGM containing sucrose and boric acid alone $\left(T_{4}\right)$. The effectiveness of BK (30) media has been reported by previous study on black gram (Vigna mungo L. VAR. DPU-88-31) with $73.00 \%$ average pollen germination (55). Whereas around 44.25 to $55.00 \%$ pollen germination was observed among Momordica sp. germinated media containing sucrose and boric acid alone (3).

Effects of boron and myo-inositol on pollen development in pollen germination media (PGM)

Bursting and lysis of pollen tube and pollen grains were also observed in different media (Fig. 3). In addition, $T_{1}, T_{2}$

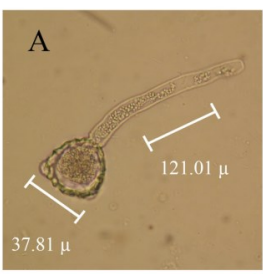

VU $005\left(\mathrm{~T}_{4}\right)$

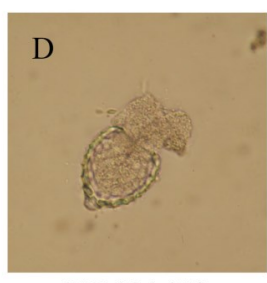

VU $004\left(\mathrm{~T}_{3}\right)$

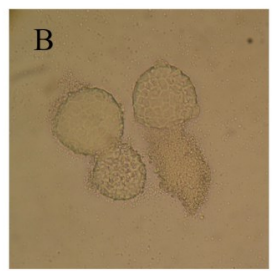

VU $002\left(T_{1}\right)$

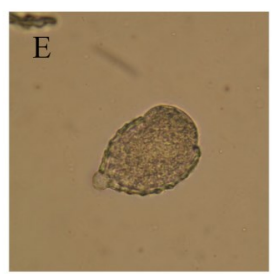

VU $006\left(\mathrm{~T}_{3}\right)$

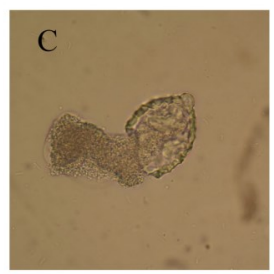

VU $005\left(\mathrm{~T}_{2}\right)$

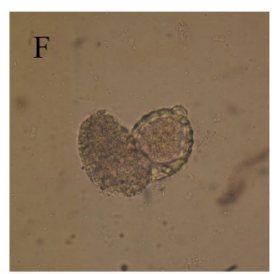

VU $007\left(\mathrm{~T}_{5}\right)$
Fig. 3. Normal (A) and burst/lysed (B-F) pollen tube and pollen grains as a response to varying media formulation in rice bean ( $\mathrm{V}$. umbellata) using a compound light microscope at $400 x$ total magnification. resulted in shorter, swelled and increase in diameter of pollen tubes in Malus domestica trees (57). In the present study, $50 \%$ increase in boron, in the form of boric acid $\left(T_{2}\right)$, also increases the pollen germination rate at around $10.21 \%$. However, an $80 \%\left(\mathrm{~T}_{4}\right)$ increase of the salt caused $17.73 \%$ decrease in germination rate. Similar findings were reported in Picea meyeri PGM, treated with 0.001 to $0.01 \%$ boric acid, where germination rates ranged from 38 to $61 \%$ (58).

The role of myo-inositol in pollen tube development has been reported in previous studies $(59,60)$. Higher plants utilize uronosyl and pentosyl, a derivative of myoinositol present in the cell wall, for polysaccharide formation and synthesis of exudates found on the stigma and style (61-63). While in this study, myo-inositol inhibits germination by 54.68 to $98.71 \%\left(T_{5}-T_{6}\right)$, in addition to no germination observed in some rice bean ( $V$. umbellata) accessions. The lower germination result can be attributed to the regulating capacity of inositol polyphosphate kinase reported in Arabidopsis (AtIPK2a). Previous study revealed that the reduction in AtIPK2a transcript levels resulted in enhanced pollen germination and pollen tube growth of transgenic Arabidopsis thaliana, under nonoptimal low $\mathrm{Ca}^{2+}$ concentrations culture medium (64).

\section{Effects of stages in flowering in in vitro pollen germina-} tion

To determine the most efficient phase of rice bean for pollen germination, pollen grains from different flowering stages (bud phase, anthesis and post-anthesis) were germinated in the artificial media. Germinated pollen grains developed longer pollen tube compare to the diameter of the ungerminated pollen itself (Fig. 4).

Individual treatment composition showed variable effects of pollen germination at different flowering stages. BK (30) medium with 0.2 g. $\mathrm{l}^{-1}$ boric acid $\left(\mathrm{T}_{2}\right)$ exhibited a relatively higher germination rate with $34.68 \%$, combining the 


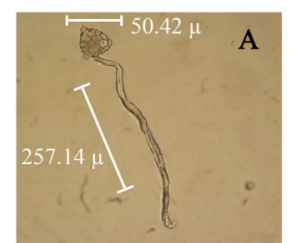

VU $006\left(\mathrm{~T}_{1}\right)$

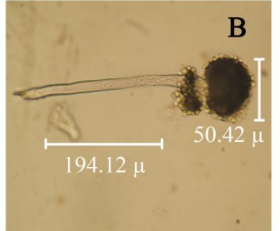

VU $006\left(\mathrm{~T}_{2}\right)$

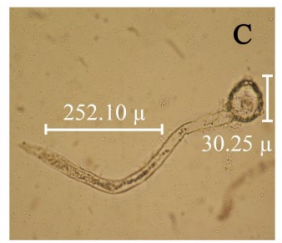

VU $002\left(\mathrm{~T}_{2}\right)$
Fig. 4. Germinated pollen (pollen tube length is greater than pollen diameter) in different media during bud phase (A), anthesis (B), and post-anthesis (C) using a compound light microscope at $400 x$ total magnification.

germination rate in all phases (Fig. 5). The same treatment was also observed to have a higher germination rate in bud pollens $(14.96 \pm 1.53 \%)$ and post-anthesis pollens $(10.28 \pm$ $0.94 \%)$. Boron, in the form of boric acid, plays an essential

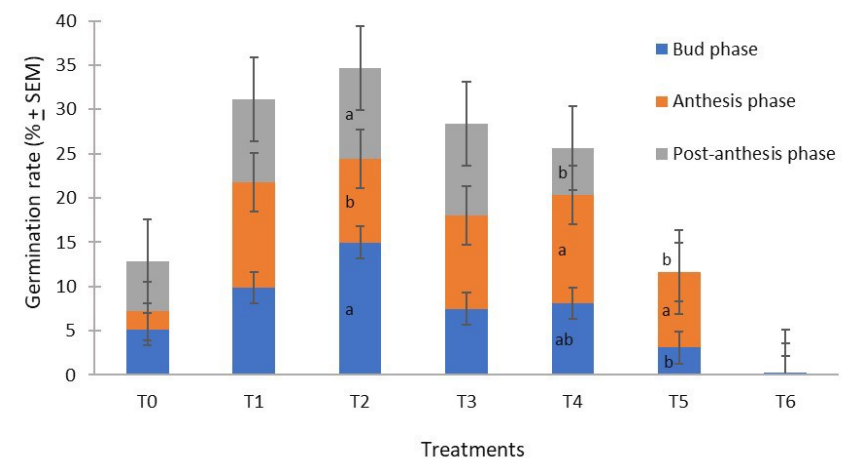

Fig. 5. Pollen germination rate among rice bean ( $V$. umbellata) accessions in different stages of flowering.

role in in vitro pollen germination by regulating the pollen tube growth through its ability to stimulate the plasma membrane $\mathrm{H}^{+}$-ATPase (65). Contrasting results were obtained in in vitro pollen germination in Chinese fir (Cunnighamia lanceolata L.) using the same concentration of boric acid, which completely inhibited pollen germination (66). They further stated that not using the optimal concentration of boric acid hinders pollen germination. Based on the current findings and the previous results, the optimum boron requirement varied in every species (57).

On the other hand, anthesis pollens have the highest germination rate in modified Gaaliche et al. (28) media

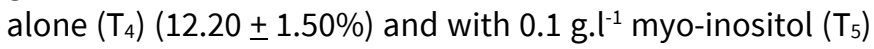
supplementation $(8.49 \pm 1.86 \%)$. Myo-inositol has been incorporated in several growth media and has the ability to stimulate pollen tube growth in some plant species and cell wall biosynthesis $(60,67,68)$. The effects of PGM composition in pollen germination at different flowering stages has also been reported in passion fruit (Passiflora spp.), having 24.08 to $54.87 \%$ higher in anthesis compared to post and pre-anthesis (69).

\section{Incompatibility in rice bean (V. umbellata)}

Compatibility refers to the ability of the stigma to recognize and accepts the pollen grains. The process is highly selective and a factor determining the quantitative and qualitative productivity aspects of agronomic crops (70). In the current study, each accession was cross-pollinated in vivo, and germination rate and pollen penetration in style were determined. The result showed $26.57 \pm 2.49 \%$ germination rate among accession crosses. Highest and significant mean rate $(p \leq 0.05)$ was observed in three cross-pairs (male $x$ female) namely VU 002 x VU 004 (55.12 + 11.35\%), VU 004 x VU 007 (54.53 $\pm 6.79 \%)$, and VU $002 \times$ VU 005 (51.83 $\pm 5.49 \%$ ) (Table 3). In addition, VU $004 \times$ VU 007 has the

Table 3. Cross-compatible pollen-stigma interaction and style penetration in rice bean (V. umbellata) accessions.

\begin{tabular}{|c|c|c|c|}
\hline \multicolumn{2}{|c|}{ PARENT COMBINATION } & \multirow[b]{2}{*}{$\begin{array}{l}\text { GERMINATION RATE (+ } \\
\text { SEM) IN STIGMA }\end{array}$} & \multirow[b]{2}{*}{$\begin{array}{l}\text { POLLEN PENETRATION } \\
\text { IN A SINGLE STYLE }\end{array}$} \\
\hline $\begin{array}{l}\text { Male (Pollen } \\
\text { Source) }\end{array}$ & $\begin{array}{c}\text { Female } \\
\text { (Pollen Re- } \\
\text { ceptor) }\end{array}$ & & \\
\hline VU 001 & VU 002 & $46.24 \pm 11.53^{\mathrm{ab}}$ & + \\
\hline VU 001 & VU 004 & $0.00^{c}$ & - \\
\hline VU 001 & VU 005 & $6.30 \pm 6.30^{c}$ & \pm \\
\hline VU 001 & VU 006 & $2.29 \pm 2.29^{c}$ & - \\
\hline VU 001 & VU 007 & $3.99 \pm 3.99^{c}$ & - \\
\hline VU 002 & VU 001 & $3.62 \pm 3.62^{c}$ & - \\
\hline VU 002 & VU 004 & $55.12 \pm 11.35^{\mathrm{a}}$ & \pm \\
\hline VU 002 & VU 005 & $51.83 \pm 5.49^{a}$ & ++ \\
\hline VU 002 & VU 006 & $43.49 \pm 2.37^{\mathrm{ab}}$ & ++ \\
\hline VU 002 & VU 007 & $41.75 \pm 3.27^{\mathrm{ab}}$ & ++ \\
\hline VU 004 & VU 001 & $47.58 \pm 1.12^{\mathrm{ab}}$ & ++ \\
\hline VU 004 & VU 002 & $42.63 \pm 9.68^{a b}$ & + \\
\hline VU 004 & VU 005 & $42.56 \pm 6.41^{\mathrm{ab}}$ & \pm \\
\hline VU 004 & VU 006 & $34.39 \pm 6.20^{\mathrm{ab}}$ & \pm \\
\hline VU 004 & VU 007 & $54.53 \pm 6.79^{a}$ & +++ \\
\hline VU 005 & VU 001 & $48.39 \pm 7.97^{\mathrm{ab}}$ & ++ \\
\hline VU 005 & VU 002 & $0.00^{c}$ & - \\
\hline VU 005 & VU 004 & $6.67 \pm 6.67^{c}$ & \pm \\
\hline VU 005 & VU 006 & $8.23 \pm 8.23^{c}$ & ++ \\
\hline VU 005 & VU 007 & $49.60 \pm 5.45^{\mathrm{ab}}$ & \pm \\
\hline VU 006 & VU 001 & $34.18 \pm 18.77^{a b}$ & \pm \\
\hline VU 006 & VU 002 & $3.24 \pm 3.24^{c}$ & \pm \\
\hline VU 006 & VU 004 & $0.00^{c}$ & - \\
\hline VU 006 & VU 005 & $0.00^{c}$ & - \\
\hline VU 006 & VU 007 & $48.87 \pm 10.10^{a b}$ & \pm \\
\hline VU 007 & VU 001 & $37.98 \pm 10.04^{a b}$ & + \\
\hline VU 007 & VU 002 & $27.81 \pm 1.11^{b}$ & \pm \\
\hline VU 007 & VU 004 & $50.00 \pm 1.31^{\mathrm{ab}}$ & + \\
\hline VU 007 & VU 005 & $5.65 \pm 5.65^{c}$ & \pm \\
\hline VU 007 & VU 006 & $0.00^{c}$ & - \\
\hline \multicolumn{2}{|c|}{ Average } & $26.57 \pm 2.49$ & \pm \\
\hline
\end{tabular}

highest pollen penetration observed in style. The table also showed no germination observed in some crosses (VU $001 \mathrm{x}$ VU 004, VU 005 x VU 002, VU 006 x VU 004, VU 006 x VU 005, and VU $007 \times$ VU 008). Previous reports mentioned that failure germination could be caused by pollen tubes that are unable to penetrate the stigma and style, embryo abortion during embryogenesis, and the most common in legumes, embryo degeneration (33). The intra-specific incompatibility observed in some rice bean ( $V$. umbellata) accession is due to swelling of pollen tubes (Fig. 6). Swollen tube was also observed in wild and cultivated sesame (Sesamum indicum) (71). Delayed pollen tube growth along with other structural abnormalities like twisting, swelling, high branching, bi-furcated tip and variation in callose form were also noticed in the interspecific crosses of Abelmoschus spp. (72). 


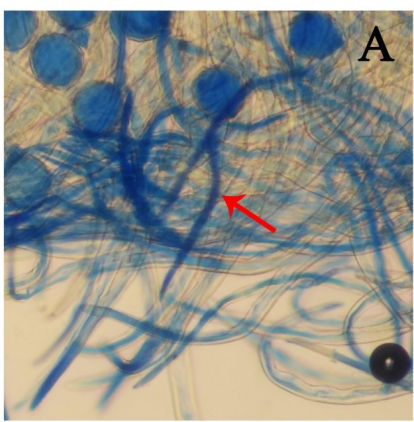

VU 007 x VU 002

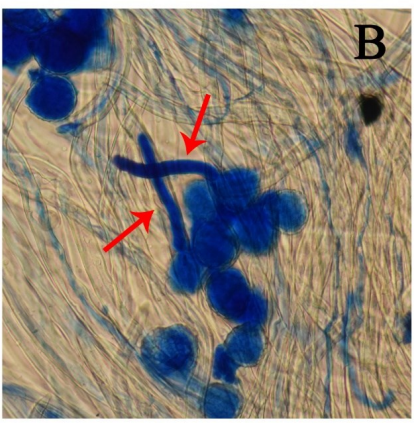

VU $002 \times$ VU 006

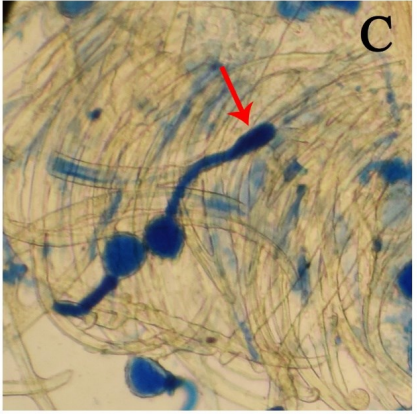

VU 004 x VU 006

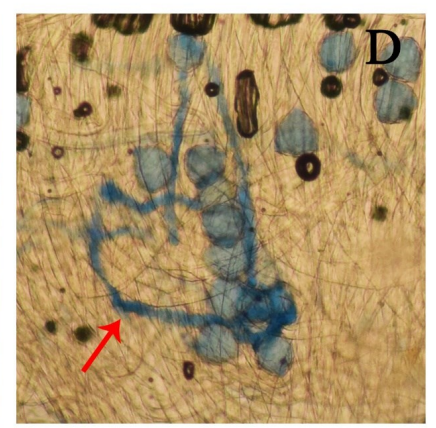

VU 005 x VU 007

Fig. 6. Normal (A) and swollen (B-D) pollen tube (pointed by an arrow) in incompatible inter-specific crosses (male x female) of rice bean ( $\mathrm{V}$. umbellata) using a compound light microscope at 400x total magnification.

No significant difference was observed among selfpollinated accessions (Table 4); however, the highest germination rate was observed in VU $001(64.01 \pm 1.83 \%)$. The

Table 4. Self-compatible pollen-stigma interaction and style penetration in rice bean ( $V$. umbellata) accessions.

\begin{tabular}{|c|c|c|c|}
\hline \multicolumn{2}{|c|}{ PARENT COMBINATION } & \multirow[b]{2}{*}{$\begin{array}{l}\text { GERMINATION RATE } \\
\text { ( } \pm \text { SEM) IN STIGMA }\end{array}$} & \multirow[b]{2}{*}{$\begin{array}{l}\text { POLLEN PENETRATION IN } \\
\text { A SINGLE STYLE }\end{array}$} \\
\hline $\begin{array}{l}\text { Male (Pollen } \\
\text { Source) }\end{array}$ & $\begin{array}{c}\text { Female } \\
\text { (Pollen } \\
\text { Receptor) }\end{array}$ & & \\
\hline VU 001 & VU 001 & $64.01 \pm 1.83$ & \pm \\
\hline VU 002 & VU 002 & $47.44 \pm 4.92$ & \pm \\
\hline VU 004 & VU 004 & $45.33 \pm 13.32$ & \pm \\
\hline VU 005 & VU 005 & $43.94 \pm 7.96$ & - \\
\hline VU 006 & VU 006 & $54.85 \pm 10.98$ & \pm \\
\hline VU 007 & VU 007 & $48.98 \pm 8.67$ & \pm \\
\hline \multicolumn{2}{|c|}{ Average } & $50.76 \pm 3.45$ & \pm \\
\hline
\end{tabular}

average germination rate of self-pollinated accessions is $47.66 \%$ higher than the cross-pollinated accessions. Like cowpea (Vigna unguiculata (L.) Walp.), rice bean (V. umbellata) is self-pollinated with somatic chromosome number of $22(73,74)$, resulting in higher self-compatibility and pollen tube growth. Similar results were found out in the preceding studies on in vivo pollen tube growth of selfpollinated Vigna spp. with normal and high pollen grain germination (75).

\section{Conclusion}

Based on the acetocarmine calorimetric assay findings, the pollen grains of indigenous accessions of rice beans $(\mathrm{V}$. umbellata) are highly viable, with accessions VU 004 and VU 007 having the optimum viability rate. In general, BK medi-

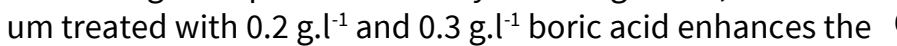
germination rate in vitro. Bud and post-anthesis pollens have optimum germination rate when supplemented at 0.2 g. . $^{-1}$ boric acid media, while anthesis pollens are suitable in myo-inositol supplemented media. Rice bean ( $V$. umbellata) accessions have lower interspecific compatibility but have higher self-compatibility.

\section{Acknowledgements}

The study was funded by the Cebu Technological University through the General Appropriation Act (GAA) and Special Trust Fund grants.

\section{Authors contributions}

MLDP, JAP and MCN designed the study, led and supervised the experimental setups, performed data analysis and checked the manuscript. JHR assisted the experiments, collected data and drafted the manuscript.

\section{Compliance with ethical standards}

Conflict of interest: Authors do not have any conflict of interests to declare.

Ethical issues: None.

\section{References}

1. Tushabe D, Rosbakh S. A Compendium of in vitro germination media for pollen research. Front Plant Sci. 2021;12:1-14. https:// doi.org/10.3389/fpls.2021.709945

2. Webster AD. Factors Influencing the flowering, fruit set and fruit growth of european pears. Acta Hort. 2002;596:699-709. https:// doi.org/10.17660/actahortic.2002.596.121

3. Rathod V, Behera TK, Munshi AD, Durgesh K, Jat GS, Krishnan BG, Sharma N. Pollen viability and in vitro pollen germination studies in Momordica species and their intra and interspecific hybrids. Int J Chem Stud. 2018;6(6):32-40.

4. Kumarihami PCH, Oh EU, Nesumi A, Song KJ. Comparative study on cross-compatibility between Camellia sinensis var. sinensis (China type) and C. sinensis var. assamica (Assam type) tea. Afr J Agric Res. 2016;11(12):1092-1101. https://doi.org/10.5897/ AJAR2015.9951

Wheeler M, de Graaf B, Hadjiosif N, Perry R, Poulter N, Osman K, Vatovec S, Harper A, Franklin C, Franklin-Tong V. Identification of the pollen self-incompatibility determinant in Papaver rhoeas. Nature. 2009;459:992-97. https://doi.org/10.1038/nature08027

6. Pratap A, Malviya N, Tomar R, Gupta DS, Kumar J. Vigna. In: Pratap A, Kumar J, (editors). Alien gene transfer in crop plants. New York: Springer; 2013:2:163-89. https://doi.org/10.1007/978-1 $-4614-9572-7$

7. Song XF, Ren SC, Liu CM. Peptide hormones. In: Li J, Li C, Smith SS, editors. Hormone metabolism and signalling in plants. Academic Press; 2017:361-404. https://doi.org/10.1016/b978-0-12811562-6.00011-6

8. Kermicle JL, Evans MMS. The Zea mays sexual compatibility gene ga2: naturally occurring alleles, their distribution and role in reproductive isolation. J Hered. 2010;101:737-49. https:// doi.org/10.1093/jhered/esq090 
9. de Nettancourt D. Incompatibility and incongruity in wild and cultivated plants. 2nd ed. Berlin: Springer; 2001. https:// doi.org/10.1007/978-3-662-04502-2

10. Maune JF, Camadro EL, Erazzú LE. Cross-incompatibility and selfincompatibility: unrelated phenomena in wild and cultivated potatoes?. Botany. 2018;96(1):33-45. https://doi.org/10.1139/cjb2017-0070

11. Bhanu AN, Singh MN, Srivastava K. Crossability studies of interspecific hybridization among Vigna species. Biomed J Sci and Tech Res. 2018;2(5):1-7. https://doi.org/10.26717/ BJSTR.2018.02.000818

12. Singh SK, Singh MN, Choudhary VK, Singh MK, Tigga A. Studies on the interspecific hybrids between mungbean and urdbean. Int J Curr Microbiol App Sci. 2020;9(05):364-69. https:// doi.org/10.20546/ijcmas.2020.905.041

13. Sulusoglu M, Cavusoglu A. In vitro pollen viability and pollen germination in cherry laurel (Prunus laurocerasus L.). Sci World J. 2014. https://doi.org/10.1155/2014/657123

14. Lankinen A, Lindstrom SAM, D'Hertefeldt T. Variable pollen viability and effects of pollen load size on components of seed set in cultivars and feral populations of oilseed rape. PLoS One. 2018;13(9):e0204407. journal.pone.0204407

https://doi.org/10.1371/

15. Ribeiro GS, Ferreira AF, Neves CM, Sousa FS, de Oliveira C, Alves EM, Sodré G, de Carvalho CA. Aspects of the floral biology and pollen properties of Vigna unguiculata L. Walp (Fabaceae). Afr J Plant Sci. 2013;7(5):149-54. https://doi.org/10.5897/AJPS13.1014

16. Chijioke OB, Ifeanyi UM, Blessing AC. Pollen behaviour and fertililization impairment in Bambara groundnut (Vigna subterrenea (L.) Verdc.). J Plant Breed Crop Sci. 2010;2:12-23.

17. Sudha M, Anusuya P, Mahadev NG, Karthikeyan A, Nagarajan P, Raveendran M, Senthil N, Pandiyan M, Angappan K, Balasubramanian $\mathrm{P}$. Molecular studies on mungbean (Vigna radiata (L.) Wilczek) and ricebean (Vigna umbellata (Thunb.)) interspecific hybridisation for mungbean yellow mosaic virus resistance and development of species-specific SCAR marker for ricebean. Arch. Phytopathol. Pflanzenschutz. 2013;46(5):503-17. https:// doi.org/10.1080/03235408.2012.745055

18. Pandiyan M, Ramamoorthi N, Ganesh SK, Jebaraj S, Pagarajan P, Balasubramanian P. Broadening the genetic base and introgression of MYMV resistance and yield improvement through unexplored genes from wild relatives in mungbean. Plant Mutation Rep. 2008;2:33-38.

19. Singh CM, Singh P, Pratap A, Pandey R, Purwar S, Vibha, Douglas $\mathrm{CA}$, Baek K-H, Mishra AK. Breeding for enhancing legumovirus resistance in mungbean: current understanding and future directions. Agronomy. 2019;9:1-25. https://doi.org/10.3390/ agronomy9100622

20. Pandiyan M, Krishnaveni A, Sivakumar A, Sivakumar C, Vaithilingan M, Jamuna E, Radhakrishnan V, Sivakumar B, Senthilkumar P. Development of mungbean yellow mosaic virus (MYMV) resistant genotypes in greengram through introgression of wild genotypes. Int J Curr Microbiol App Sci. 2020;9(6):3787-93. https://doi.org/10.20546/ijcmas.2020.906.449

21. Nair RM, Götz M, Winter S, Giri RR, Boddepalli VN, Sirari A, Bains TS, Taggar GK, Dikshit HK, Aski M, Boopathi M, Swain D, Rathore A, Anil Kumar V, Lii EC, Kenyon L. Identification of mungbean lines with tolerance or resistance to yellow mosaic in fields in India where different begomovirus species and different Bemisia tabaci cryptic species predominate. Eur J Plant Pathol. 2017;149:349-65. https://doi.org/10.1007/s10658-017-1187-8

22. Pattanayak A, Roy S, Sood S, langrai B, Banerjee A, Gupta S, Joshi DC. (2019). Rice bean: a lesser known pulse with well-recognized potential. Planta. 2019. https://doi.org/10.1007/s00425-01903196-1
23. Bepary RH, Wadikar DD, Neog SB, Patki PE. Studies on physicochemical and cooking characteristics of rice bean varieties grown in NE region of India. J Food Sci Technol. 2016;54:973-86. https:// doi.org/10.1007/s13197-016-2400-z

24. Katoch R. Nutritional potential of rice bean (Vigna umbellata): An underutilized legume. J Food Sci. 2013;78(1):8-16. https:// doi.org/10.1111/j.1750-3841.2012.02989.x

25. Basavaraja T, Murthy N, Vijay Kumar L, Mallikarjun K. Studies on cross compatibility in interspecific crosses of Vigna radiata $\times$ Vigna umbellata species. Legume Research. 2019;42(5):699-704. https://doi.org/10.18805/LR-3974

26. Chen M, Zuo X-A. Pollen limitation and resource limitation affect the reproductive success of Medicago sativa L. BMC Ecol. 2018;18:1-10. https://doi.org/10.1186/s12898-018-0184-X

27. Grigoryan K. Safety of Honey. In: Prakash V, Martin-Belloso O, Keener L, Astley SB, Braun S, McMahon H, Lelieveld H, (editors). Regulating safety of traditional and ethnic foods [e-book]. Academic Press; 2016:217-46. https://doi.org/10.1016/B978-0-12800605-4.00012-8

28. Gaaliche B, Majdoub A, Trad M, Mars M. Assessment of pollen viability, germination and tube growth in eight Tunisian caprifig (Ficus carica L.) cultivars. ISRN Agronomy. 2013;1-4. https:// doi.org/10.1155/2013/207434

29. Abdelgadir HA, Johnson SD, Van Staden J. Pollen viability, pollen germination and pollen tube growth in the biofuel seed crop Jatropha curcas (Euphorbiaceae). S Afr J Bot. 2012;79:132-39. https://doi.org/10.1016/j.sajb.2011.10.005

30. Brewbaker JL, Kwack BH. The essential role of calcium ion in pollen germination and pollen tube growth. Am J Bot. 1963;50 (9):859-65. https://doi.org/10.1002/j.1537-2197.1963.tb06564.x

31. Diamantino MSAS, Costa MAP, Soares TL, Morais DV, Silva SA, Hilo de Souza E. Morphology and viability of castor bean genotypes pollen grains. Acta Sci-Agron. 2016;38(1):77-83. https:// doi.org/10.4025/actasciagron.v38i1.25981

32. García-Tierrablanca EA, Raya-Pérez JC, Covarrubias-Prieto J, Dorantes-González JAR, Chablé-Moreno F, Ramírez-Pimentel JG, Aguirre-Mancilla C. Assessment of emasculation techniques and maturation of fruit for seed production of pepper (Capsicum annuum L.). Rev Mex Cienc Agríc. 2015;6: 2129-37. https:// doi.org/10.29312/remexca.v0i11.782

33. Bhanu NA, Singh MN, Srivastava K. Efficient hybridization procedure for better pod setting in inter-specific crosses involving vigna species. Adv Plants Agric Res. 2018;8(2):101-05. https:// doi.org/10.15406/apar.2018.08.00298

34. Bomfim IGA, Bezerra AD, Nunes AC Freitas BM, de Aragão FES. Pollination requirements of seeded and seedless mini watermelon varieties cultivated under protected environment. Pesq agropec bras. 2015;50:44-53. https://doi.org/10.1590/S0100204X2015000100005

35. Chen J-C, Fang S-C. The long pollen tube journey and in vitro pollen germination of Phalaenopsis orchids. Plant Reprod. 2016;29:179-88. https://doi.org/10.1007/s00497-016-0280-z

36. Dafni A, Firmage D. Pollen viability and longevity: practical, ecological and evolutionary implications. Plant Syst Evol. 2000;222:113-32. https://doi.org/10.1007/BF00984098

37. dos Santos KS, Passos AR, Serejo JA, Lino LS, Figueiredo MC, Santos RM. Microsporogenesis and pollen viability in Physalis ixocarpa. Cytologia. 2017;82(4):363-67. https://doi.org/10.1508/ cytologia. 82

38. Krycki KC, Simioni C, Dall'Agnol M. Cytoembryological evaluation, meiotic behavior and pollen viability of Paspalum notatum tetraploidized plants. Crop Breed. Appl. Biotechnol. 2016;16:28288. http://dx.doi.org/10.1590/1984-70332016v16n4a43 
39. Palma-Silva C, dos Santos DG, Kaltchuk-Santos E, BodaneseZanettini MH. Chromosome numbers, meiotic behavior and pollen viability of species of Vriesea and Aechmea genera (bromeliaceae) native to Rio Grande Do Sul, Brazil. Am J Bot. 2004;91(6):804-07. https://doi.org/10.3732/ajb.91.6.804

40. Dapson RW. The history, chemistry and modes of action of carmine and related dyes. Biotechnic and Histochemistry. 2007;82(4 -5):173-87. https://doi.org/10.1080/10520290701704188

41. Kaur D, Singhal VK. Meiotic abnormalities affect genetic constitution and pollen viability in dicots from Indian cold deserts. BMC Plant Biol. 2019;19(10):1-11. https://doi.org/10.1186/s12870-0181596-7

42. Singhal VK, Kumar P. Impact of cytomixis on meiosis, pollen viability and pollen size in wild populations of Himalayan poppy (Meconopsis aculeata Royle). J Biosci. 2008;33(3):371-80. https:// doi.org/10.1007/s12038-008-0057-0

43. Avci S, Sancak C, Can A, Acar A, Pinar NM. Pollen morphology of the genus Onobrychis (Fabaceae) in Turkey. Turk J Bot. 2013;37:669-81. https://doi.org/10.3906/bot-1207-52

44. Banks H, G. Lewis. Phylogenetically informative pollen structures of "caesalpinioid" pollen (Caesalpinioideae, Cercidoideae, Detarioideae, Dialioideae and Duparquetioideae: Fabaceae). Bot J Linn Soc. 2018;187(1):59-86. https://doi.org/10.1093/botlinnean/ boy005

45. Zulkarnain Z, Eliyanti E, Swari, El. Pollen viability and stigma receptivity in Swainsona formosa (G.Don) J. Thompson (Fabaceae), an ornamental legume native to Australia. Ornam Hortic. 2019;25(2):158-67. https://doi.org/10.14295/ oh.v25i2.2011

46. Merin EG, Sarada S, Celine VA. Pod set and Pollen Viability Studies in Yard Long Bean (Vigna unguiculata subsp. sesquipedalis). J Hortl Sci. 2019;14(2):169-72. https://doi.org/10.24154/ JHS.2019.v14i02.015

47. Yankova-Tsvetkova E, Yurukova-Grancharova P, Vitkova A. Reproductive biology of the Balkan endemic Sideritis scardica (Lamiaceae). Bot Serbica. 2013;37(1):83-87.

48. Longkumer $\mathrm{Y}$, Deka, SD. The significance of pollen viability and stigma receptivity on seed setting. Journal of Agroecology and Natural Resource Management. 2015;2(1):51-56.

49. Wang Y-L, Guan Z-Y, Chen F-D, Fang W-M, Teng N-J. Pollen viability, pistil receptivity, and embryo development in hybridization of Nelumbo nucifera Gaertn. Sci World J. 2012;1-8. https:// doi.org/10.1100/2012/678706

50. López Díaz S, Rodríguez Garay B. Simple methods for in vitro pollen germination and pollen preservation of selected species of the genus Agave. e-Gnosis (online). 2008;6:1-7.

51. Jayaprakash P, Annapoorani S, Vikas VK, Sivasamy M, Kumar J, Saravannan K, Punniakotti E, Sheeba D. An improved in vitro germination medium for recalcitrant bread wheat (Triticum aestivum L.) pollen. Indian J Genet. 2015;75(4):446-52. https:// doi.org/10.5958/0975-6906.2015.00072.3

52. Jayaprakash P. Pollen germination in vitro. In: Mokwala PW, (editor). Pollination in plants. Copenhagen; IntechOpen: 2018: 97 -103. https://doi.org/10.5772/intechopen.75360

53. Jayaprakash P, Sheeba D, Vikas VK, Sivasamy M, Sabesan T. Development of pollen germination medium to test pollen viability of eggplant and its wild species. Indian J Hort. 2018;75(2): 237-44. https://doi.org/10.5958/0974-0112.2018.00041.5

54. Chatterjee R, Sarkar S, Narasimha Rao, GM. Improvised media for in vitro pollen germination of some species of Apocynaceae. Int J Environ. 2014;3(3):146-53. https://doi.org/10.3126/ije.v3i3.11074

55. Pandey N, Gupta B. Improving seed yield of black gram (Vigna mungo L. var. DPU-88-31) through foliar fertilization of zinc dur- ing the reproductive phase. J Plant Nutr. 2012;35(11):1683-92. https://doi.org/10.1080/01904167.2012.698349

56. Muengkaew R, Chaiprasart $P$, Wongsawad P. Calcium-Boron addition promotes pollen germination and fruit set of mango. Int J Fruit Sci. 2017;12(2):147-58. https:// doi.org/10.1080/15538362.2016.1259085

57. Fang $\mathrm{K}$, Zhang W, Xing Y, Zhang Q, Yang L, Cao Q, Qin L. Boron toxicity causes multiple effects on Malus domestica pollen tube growth. Front Plant Sci. 2016;7:1-12. https://doi.org/10.3389/ fpls.2016.00208

58. Wang Q, Lu L, Wu X, Li Y, Lin J. Boron influences pollen germination and pollen tube growth in Picea meyeri. Tree Physiol. 2003;23:345-51. https://doi.org/10.1093/TREEPHYS/23.5.345

59. Kroh M, Miki-Hirosige H, Rosen W, Loewus F. Inositol metabolism in plants: VII. Distribution and utilization of label from myoinositol-U-' $4 \mathrm{C}$ and $-2-3 \mathrm{H}$ by detached flowers and pistils of Lilium longiflorum. Plant Physiol. 1970;45:86-91. https:// doi.org/10.1104/pp.45.1.86

60. Rodriguez-Enriquez MJ, Mehdi S, Dickinson HG, Grant-Downton RT. A novel method for efficient in vitro germination and tube growth of Arabidopsis thaliana pollen. New Phytol. 2013;197:66879. https://doi.org/10.1111/nph.12037

61. Mandal AB, Sharma A. Effect of boron and myo-inositol on pollen tube growth of hybrid of bread wheat (Triticum Aestivum L. Emend. Thell.). IOSR-JAVS. 2017;10(4):26-31. https:// doi.org/10.9790/2380-1004012631

62. Kroh M, Miki-Hirosige H, Rosen W, Loewus F. Incorporation of label into pollen tube walls from myoinositol-labeled Lilium longiflorum pistils. Plant Physiol. 1970;45:92-94. https:// doi.org/10.1104/pp.45.1.92

63. Loewus FA. Inositol and plant cell wall polysaccharide biogenesis. In: Lahiri Majumder A, Biswas BB, (editors). Biology of inositols and phosphoinositides. Netherlands: Springer; 2006:39:2145. https://doi.org/10.1007/0-387-27600-9_2

64. Xu J, Brearley CA, Lin W-H, Wang Y, Ye R, Mueller-Roeber B, Xu Z$\mathrm{H}$, Xue, H-W. A role of arabidopsis inositol polyphosphate kinase, AtIPK2a, in pollen germination and root growth. Plant Physiol. 2005;137:94-103. https://doi.org/10.1104/pp.104.045427

65. Holdaway-Clarke TL, Hepler PK. Control of pollen tube growth: role of ion gradients and fluxes. New Phytol. 2003;159(3):539-63. https://doi.org/10.1046/j.1469-8137.2003.00847.x

66. Fragallah SADA, Lin S, Li N, Ligate EJ, Chen Y. Effects of sucrose, boric acid, $\mathrm{pH}$, and incubation time on in vitro germination of pollen and tube growth of Chinese fir (Cunnighamia lanceolata L.). Forest. 2019;10:1-16. https://doi.org/10.3390/f10020102

67. Kanter U, Usadel B, Guerineau F, Li Y, Pauly M, Tenhaken R. The inositol oxygenase gene family of Arabidopsis is involved in the biosynthesis of nucleotide sugar precursors for cell-wall matrix polysaccharides. Planta. 2005;221(2):243-54. https:// doi.org/10.1007/s00425-004-1441-0

68. Schneider S, Schneidereit A, Konrad KR, Hajirezaei MR, Gramann M, Hedrich R, Sauer N. Arabidopsis INOSITOL TRANSPORTER4 mediates high-affinity $\mathrm{H}^{+}$symport of myoinositol across the plasma membrane. Plant Physiol. 2006;141(2):565-77. https:// doi.org/10.1104/pp.106.077123

69. Soares TL, De Jesus ON, Dos Santos-Serejo JA, De Oliveira EJ. In vitro pollen germination and pollen viability in passion fruit (Passiflora spp.). Rev Bras Frutic. 2013;35(4):1116-26. https:// doi.org/10.1590/S0100-29452013000400023

70. Mandrone M, Antognoni F, Aloisi I, Potente G, Poli F, Cai G, Faleri G, Parrotta L, Del Duca, L. Compatible and incompatible pollenstyles interaction in Pyrus communis L. show different transglutaminase features, polyamine pattern and metabolomics profiles. Front Plant Sci. 2019;10:1-13. https://doi.org/10.3389/ fpls.2019.00741 
71. Ganesh Ram S, Sundaravelpandian K, Kumar M, Vinod KK, Kan- 74. Nameirakpam B, Khanna VK. Studies on crossability and genetic nan Bapu JR, Raveendran TS. Pollen-pistil interaction in the inter -specific crosses of Sesamum sp. Euphytica. 2006;152:379-85. https://doi.org/10.1007/s10681-006-9225-1 diversity in cowpea (Vigna unguiculata (L.) Walp.). Int J Environ Sci Nat Res. 2018;13(1):8-16. https://doi.org/10.19080/ IJESNR.2018.12.555852.

72. Patil P, Malik SK, Negi KS, John J, Yadav S, Chaudhari G, Bhat KB. Pollen germination characteristics, pollen-pistil interaction and reproductive behaviour in interspecific crosses among Abelmoschus esculentus Moench and its wild relatives. Grana. 2013;52:1-14. https://doi.org/10.1080/00173134.2013.768699

75. Thiyagu K, Jayamani P, Nadarajan N. Pollen pistil interaction in inter-specific crosses of Vigna sp. Cytologia. 2008;73(3):251-57. https://doi.org/10.1508/cytologia.73.251

73. Venkataramana PB, Gowda R, Somta P, Ramesh S, Mohan Rao A, Bhanuprakash K, Srinives P, Gireesh C, Pramila CK. Mapping QTL for bruchid resistance in rice bean (Vigna umbellata). Euphytica. 2016;207:135-47. https://doi.org/10.1007/s10681-015-1551-8 